\title{
In vitro and in vivo antibacterial and anti-inflammatory effect of catechin including pharmacokinetic profile in rat
}

\author{
Raseshkumar D. Varia , Jatin H. Patel, Falguni D. Modi, Priti D. Vihol and Shailesh K. Bhavsar* \\ Veterinary College, Kamdhenu University, Navsari-396450, Gujarat, India. \\ *Veterinary College, Kamdhenu University, Anand--388110, Gujarat, India
}

\section{Article Info \\ Article history \\ Received 1 November 2021 \\ Revised 17 December 2021 \\ Accepted 18 December 2021 \\ Published Online 30 December 2021}

\section{Keywords}

Antibacterial

Anti-inflammatory

Catechin

Pharmacokinetic

Rat

\begin{abstract}
In vitro antibacterial effect of catechin was evaluated by determining MIC using microbroth dilution method against various gram-positive and negative typed culture and found MIC ranges from 1.25 to 10.0 $\mathrm{mg} / \mathrm{ml}$. In vivo antibacterial efficacy was measured in neutropenic rat thigh infection model and showed significant antibacterial effect. In vitro anti-inflammatory effect of catechin $(10,50$ and $100 \mu \mathrm{M})$ was assessed by measuring COX-2 enzyme inhibition via detection of PGE2 concentration and NO production inhibition in LPS treated RAW 264.7 macrophage cells; whereas, in vivo anti-inflammatory efficacy of catechin was measured in carrageenan induced rat paw oedema model. Both in vitro and in vivo protocols revealed significant anti-inflammatory effect. Concentrations and pharmacokinetic profile of catechin were determined in rat plasma by high performance liquid chromatography (HPLC) after single intramuscular administration at dose of $200 \mathrm{mg} / \mathrm{kg}$ body weight. The mean peak plasma drug concentration of $16.36 \pm$ $0.69 \mu \mathrm{g} / \mathrm{ml}$ was observed at $0.75 \mathrm{~h}$. Pharmacokinetic parameters, viz., elimination half life $\left(\mathrm{t}_{1 / 2 \beta}\right)$, apparent volume of distribution $\left(\mathrm{Vd}_{(\text {area })}\right)$, total body clearance $\left(\mathrm{Cl}_{(\mathrm{B})}\right)$ and mean residence time (MRT) were calculated as $1.79 \pm 0.17 \mathrm{~h}, 18.62 \pm 1.54 \mathrm{l} / \mathrm{kg}, 7.23 \pm 0.15 \mathrm{l} / \mathrm{h} / \mathrm{kg}$ and $1.78 \pm 0.03 \mathrm{~h}$, respectively. These results with pharmacokinetic profile suggest that catechin may be good candidate for antibacterial and antiinflammatory herbal formulation. Moreover, catechin may be used concurrent with available antibacterial and anti-inflammatory drugs to reduce resistance of microbes against drugs and side effects.
\end{abstract}

\section{Introduction}

Antimicrobial and anti-inflammatory drugs are two main pillars to treat any infectious diseases. Due to indiscriminate use of antibacterial drugs, pathogens develop resistance and discovery of newer compound is again big challenge to pharmaceutical industry. In this situation, it is desirable to explore natural molecules that have a broad spectrum action and do not induce resistance in the microbial pathogens (Parveen et al., 2020). Ethnoveterinary practices are effective alternative to antibiotics and other chemical drugs in livestock management also (Nayanabhirama, 2016; Balakrishnan et al., 2017). Amongst all phytochemicals, flavonoids exhibit major pharmacological activities, including antioxidant, cytotoxic, anticancer, antiviral, antibacterial, anti-inflammatory, antiallergic, antithrombotic, cardioprotective, hepatoprotective, neuroprotective, antimalarial, antileishmanial, antitrypanosomal and antiamebial properties (Tapas et al., 2008; Ferreyra et al., 2012; Malik et al., 2020).

Catechin is the flavonoid and the name of which is derived from catechu of the extract of Acacia catechu L., is 3,3',4',5,7pentahydroxyflavan with two steric forms of $(+)$-catechin and its enantiomer (Tsuchiya, 2001). Catechins are distributed in a variety of foods and herbs including green tea, apples, persimmons, cacaos,

Corresponding author: Dr. Raseshkumar D. Varia Assistant Professor, Veterinary College, Kamdhenu University, Navsari396450, Gujarat, India

E-mail: drraseshvet@yahoo.co.in

Tel.: +91-9998949714

Copyright (C) 2021 Ukaaz Publications. All rights reserved.

Email: ukaaz@yahoo.com; Website: www.ukaazpublications.com grapes, and berries. Catechins are widely studied for their pharmacological effects including suppression of inflammatory conditions and antimicrobial activities (Bansal et al., 2013), antioxidant activity (Grzesik et al., 2018), hepatoprotective effect (Akinmoladun et al., 2018) etc. Camellia sinensis (green tea) is the richest source of some highly bioactive catechins. Although, catechins show an exciting array of pharmacological and therapeutic effects, these compounds have poor systemic bioavailability, poor membrane permeability, instability under alkaline conditions, oxidative degradation and metabolic transformations (Mereles and Hunstein, 2011).

Very few studies are available for pharmacological effects of injectable preparation of catechin. Looking to great therapeutic potential of catechin, this study was planned to evaluate in vitro and in vivo antibacterial as well as anti-inflammatory activities of catechin in rats including its pharmacokinetic profile following intramuscular administration that may facilitate to compute its dosage regimen.

\section{Materials and Methods}

\subsection{Animals and ethical statement}

The study was conducted in female albino wistar rats $(n=24)$, weighing $305 \pm 2.60$ grams to evaluate in vivo anti-inflammatory property. After 15 days washout period, same animals were used weighing $353 \pm 4.81$ grams to evaluate in vivo antibacterial activity and another 30 animals weighing $234 \pm 8.81$ grams were used for pharmacokinetic studies. The experimental protocols were approved by Institutional Animal Ethics Committee of Veterinary College, 
Navsari, Gujarat as per the guidelines of the committee for the purpose of control and supervision of experiments on animals (CPCSEA), Government of India with permission numbers 057-VCNVPT-2018 and 058-VCN-VPT-2018.

\subsection{Chemicals and reagents}

Catechin hydrate $(>98 \%)$, lambda $(\lambda)$ carrageenan, N $\omega$-Nitro-Larginine methyl ester hydrochloride (NAME), dulbecco's modified eagle's medium-high glucose (DMEM), meloxicam, lipopolysaccharide (LPS) and 3-(4,5-dimethylthiazol-2yl)-2,5-diphenyl-2Htetrazolium bromide (MTT) were purchased from Sigma-Aldrich, St. Louis, USA. Indomethacin was obtained from Calbiochem. Triethanolamine was purchased from MP biomedicals, USA. Dimethylsulfoxide (DMSO), PEG-200, acetonitrile (HPLC grade), glacial acetic acid, normal saline (NS), sodium nitrite and 1-methyl-2 pyrrolidone were purchased from Merck Specialties Private Limited, Mumbai. Chloramphenicol, celecoxib, sulfanilamide, N-(1-naphthyl) ethylenediamine dihydrochloride (NEDD), eosin methylene blue (EMB) agar, fetal bovine serum, brain heart infusion (BHI) broth and antibiotic antimycotic solution 100X liquid were purchased from Himedia Laboratories Private Limited, Mumbai. Typed bacterial cultures were purchased from national collection of industrial microorganisms (NCIM), Pune, India and murine macrophage cell line RAW 264.7 was purchased from national centre for cell science (NCCS), Pune, India. HPLC grade de-ionized water was used in all in vitro and in vivo procedures. Prostaglandin $\mathrm{E}_{2}$ express ELISA kit (Item No. 500141) was purchased from Cayman Chemical Company, Ann Arbor, MI USA.

\subsection{In vitro antibacterial effect of catechin}

Minimum inhibitory concentrations (MICs) of catechin were determined for different gram-positive organisms like Staphylococcus aureus (ATCC25923), Streptococcus pyogenus (ATCC8668), Bacillus subtillis (ATCC9372) and gram-negative organisms like Escherichia coli (ATCC25922), Salmonella typhimurium (ATCC23564), Pseudomonas aerugonosa (ATCC27853) and Proteus mirabilis (NCIM2241) by microbroth dilution technique (Wiegand et al., 2008). Catechin stock $(40 \mathrm{mg} / \mathrm{ml})$ was prepared using triethanolamine: DMSO: water in 0.5:0.5:9.0 ratio. Chloramphenicol stock $(250 \mu \mathrm{g} /$ $\mathrm{ml}$ ) was prepared in sterile water to use as positive control. All bacterial cultures were prepared to Mcfarland 0.5 standard equivalents to $1.5 \times 10^{8} \mathrm{cfu} / \mathrm{ml}$ and final dispensing concentrations were made as $1.5 \times 10^{6} \mathrm{cfu} / \mathrm{ml}$ diluted with sterile broth. After incubation, freshly prepared $30 \mu 1$ of iodonitrotetrazolium chloride (INT) dye $(1 \mathrm{mg} / \mathrm{ml})$ was dispensed in all wells of microtiter plate for evaluation of visual viability of organisms. The assay was performed in triplicate.

\subsection{In vivo antibacterial effect of catechin}

In vivo antibacterial efficacy of catechin was evaluated in neutropenic rat thigh infection model (Zhao et al., 2016). Total twenty four rats were divided into four groups with six rats in each group. Catechin was dissolved using DMSO: PEG-200: 1-Methyl-2 pyrrolidone in 4.5:4.5:1.0 ratio for intramuscular administration in rats. Group I animals were treated with bacterial suspension $(0.2 \mathrm{ml} \mathrm{IM}$ in thigh) and chloramphenicol $(50 \mathrm{mg} / \mathrm{kg} \mathrm{IM})$ (positive control), group II animals were treated with bacterial suspension $(0.2 \mathrm{ml}, \mathrm{IM})$ and vehicle (DMSO: PEG-200: 1-methyl-2 pyrrolidone: water in ratio of 3.0: 3.0: 1.0: 3.0) (0.2 $\mathrm{ml}$, IM) (vehicle control), group III animals were treated with only bacterial suspension $(0.2 \mathrm{ml}$, IM) (growth control), group IV animals were treated with bacterial suspension $(0.2 \mathrm{ml}, \mathrm{IM})$ and catechin $(200 \mathrm{mg} / \mathrm{kg} \mathrm{IM})$. Neutropenic rat model was prepared by intraperitoneal administration of cyclophosphamide on days $1(150 \mathrm{mg} / \mathrm{kg})$ and on day $4(100 \mathrm{mg} / \mathrm{kg})$. After confirmation of neutropenic condition, rats were infected with $0.2 \mathrm{ml}$ bacterial suspension of Escherichia coli ATCC25922 $(1.5 \times 108 \mathrm{cfu} / \mathrm{ml})$ in left thigh on same day. Drugs and vehicle were administered intramuscularly at $2 \mathrm{~h}$ and $8 \mathrm{~h}$ post infection in right thigh. After 24 h, 1 gram thigh muscle samples from infected site were collected following euthanasia under sterile condition. Suitable dilution of samples were inoculated on eosin methylene blue (EMB) agar plates and incubated overnight at $37^{\circ} \mathrm{C}$, and bacterial colonies were enumerated by colony counter.

\subsection{In vitro anti-inflammatory effect of catechin}

In vitro anti-inflammatory effect of catechin was evaluated in murine macrophage cell line RAW 264.7 by measuring COX-2 enzyme inhibition via detection of $\mathrm{PGE}_{2}$ concentration and by measuring NO production inhibition. The assay was performed in triplicate. Catechin $(100 \mu \mathrm{M}, 50 \mu \mathrm{M}$ and $10 \mu \mathrm{M})$ was prepared using triethanolamine: DMSO: cell culture medium in 0.4:0.2:99.4 ratio. Macrophage cells were grown in DMEM (Varia et al., 2020).

In twelve well plate, the cells were supplemented with $1600 \mu \mathrm{l}$ cell culture medium and $200 \mu \mathrm{l}$ catechin in different concentrations (100 $\mu \mathrm{M}, 50 \mu \mathrm{M}$ and $10 \mu \mathrm{M})$. N $\omega$-nitro-L-arginine methyl ester hydrochloride (NAME, $100 \mu \mathrm{M})$ and celecoxib $(100 \mu \mathrm{M})$ were used for $\mathrm{NO}$ production inhibition assay and $\mathrm{PGE}_{2}$ inhibition assay, respectively. Vehicle control wells were treated with $1600 \mu \mathrm{l}$ cell culture medium and $200 \mu \mathrm{l}$ vehicle in which catechin was prepared and $1800 \mu \mathrm{l}$ cell culture medium was added in LPS control wells. All plates were incubated at $37^{\circ} \mathrm{C}$ and $5 \% \mathrm{CO}_{2}$ in humidified condition for two hours followed by $200 \mu \mathrm{l}$ LPS $(1 \mu \mathrm{g} / \mathrm{ml})$ was added in all wells and incubated again for twenty four hours. After incubation, supernatant was collected which was used to quantify COX-2 enzyme via measuring $\mathrm{PGE}_{2}$ concentration using prostaglandin $\mathrm{E}_{2}$ express ELISA kit (Barton et al., 2014) and to detect nitrite accumulated in medium as an indicator of NO production using griess reaction (Choi et al., 2018). Sodium nitrite standard calibration curve $(1.56 \mu \mathrm{M}$ to $50.0 \mu \mathrm{M}$ ) was prepared to validate the method of estimation and using correlation equation, concentration of NO was evaluated. Results were expressed as percent inhibition of $\mathrm{PGE}_{2}$ and $\mathrm{NO}$ production compared with LPS control. The cytotoxic effect and cell viability was evaluated after use of LPS and drugs on macrophage cells RAW 254.7 via MTT assay (Choi et al., 2018).

\subsection{In vivo anti-inflammatory effect of catechin}

The carrageenan induced rat paw edema model was used with minor modification as described by (Suebsasana et al., 2009). Experiment animals $(n=24)$ were divided into 4 groups with 6 animals in each group. Group I animals were kept as carrageenan control. Group II animals were treated with vehicle control $(200 \mu$ l DMSO: PEG-200: 1-Methyl-2 pyrrolidone in 4.5:4.5:1.0 ratio), group III animals were treated with indomethacin $(5 \mathrm{mg} / \mathrm{kg} \mathrm{IM})$ and group IV animals were treated with catechin $(200 \mathrm{mg} / \mathrm{kg} \mathrm{IM})$. A mark on the left hind paw was made in each animal and initial volume of left hind paw was measured by immersing in the plethysmometer persplex tube. Lambda carrageenan (1\%) solution prepared in $0.9 \%$ normal saline and 100 $\mu 1$ was injected subcutaneously into subplantar region of left hind 
paw. Half an hour before the carrageenan administration, test drug and positive control drug were injected via intramuscular route in respective animal groups. Oedema was measured in paw volume (ml) at $0,1,2,3,4,5$ and $6 \mathrm{~h}$ after carrageenan administration and expressed as percent oedema formation in relation to initial paw volume before carrageenan injection for each animal. The paw volume data for test drug and positive control drug were analyzed and expressed as percent inhibition of oedema formation in comparison to carrageenan control group.

\subsection{Pharmacokinetics of catechin in rat}

Animals $(n=30)$ were divided into six groups comprises of five animals in each. A single dose of catechin $(200 \mathrm{mg} / \mathrm{kg})$ was administered by intramuscular route. Catechin was dissolved in DMSO: PEG-200: 1-Methyl-2 pyrrolidone in 4.5:4.5:1.0 ratio for administration in rats. Blood samples $(250 \mu \mathrm{l})$ were collected from experimental animals in $\mathrm{K} 3 \mathrm{EDTA}$ vials, at different time interval i.e., 0 (before drug administration), 0.03 (2 $\mathrm{min}), 0.08$ (5 $\mathrm{min}), 0.167$ (10 $\mathrm{min}), 0.25$ (15 $\mathrm{min}$ ), 0.5 (30 $\mathrm{min}), 0.75$ (45 $\mathrm{min}), 1,2,4,6,8$ and $12 \mathrm{~h}$ from retro orbital plexus under light anaesthesia. Multiple numbers of rat were used for serial collection of blood at alternating time point. Plasma was separated from blood samples immediate after collection and stored under $-20^{\circ} \mathrm{C}$ until quantification of catechin. The high performance liquid chromatography instrument of Shimadzu comprises binary gradient delivery pump was used for assay. Reverse phase $\mathrm{C}_{18}$ column (ODS; $250 \times 4.6 \mathrm{~mm} \mathrm{ID)}$ ) was used to perform chromatographic separation at room temperature. Plasma was mixed with $10 \%$ glacial acetic acid in acetonitrile as 1:2 ratios to precipitate plasma protein followed by centrifugation for $15 \mathrm{~min}$ at $8000 \mathrm{rpm}$ at $4^{\circ} \mathrm{C}$ in refrigerated centrifuge. The clean supernatants were transferred into inserts of automatic sampler vial from which $20 \mu \mathrm{l}$ of supernatant was injected into HPLC system. Catechin was assayed in mobile phase and plasma. The mobile phase consisted of a mixture of acetonitrile and water (15:85 v/v) and flow rate was kept as $1.0 \mathrm{ml} /$ min at ambient temperature. The effluent was monitored at $203 \mathrm{~nm}$ wavelength (Xie et al., 2011). The software PK solution (Version 2.0) was used to integrate HPLC data. PK solution is well-known program that does pharmacokinetic data analysis following administration of drug using non-compartmental model.

Catechin standard samples $(n=4)$ with final concentrations of 25.0, $6.25,0.78$ and $0.098 \mu \mathrm{g} / \mathrm{ml}$ were prepared in mobile phase and plasma. Intraday and interday absolute recovery, precision and accuracy were evaluated to fulfil the requirement of partial validation of modified method. The C.V. of catechin in mobile phase and plasma at all concentrations studied were less than $1.89 \%$. The results showed good precision of assay. Recovery in plasma samples at all concentrations studied was above $86 \%$.

\section{Results}

\subsection{In vitro antibacterial effect}

The minimum inhibitory concentrations of catechin was determined against various gram-positive and gram-negative organisms like Staphylococcus aureus (ATCC25923), Streptococcus pyogenus (ATCC8668), Bacillus subtillis (ATCC9372), Escherichia coli (ATCC25922), Salmonella typhimurium (ATCC23564), Pseudomonas aerugonosa (ATCC27853) and Proteus mirabilis (NCIM2241) were observed as 5.0, 1.25, 5.0, 10.0, 10.0, 5.0 and $5.0 \mathrm{mg} / \mathrm{ml}$, respectively.

\subsection{In vivo antibacterial effect of catechin}

In vivo antibacterial efficacy of catechin was determined using neutropenic rat thigh infection model in which Escherichia coli colony count were carried out and converted into $\log _{10} \mathrm{CFU} / \mathrm{ml}$ for catechin (Table 1). Catechin was found to have statistically significant antibacterial property compared to growth and vehicle control (Figure 1).

Table 1: $\log 10 \mathrm{CFU} / \mathrm{ml}$ of Escherichia coli $(1.5 \times 108 \mathrm{CFU} / \mathrm{ml})$ in infected thigh samples of rats treated with drugs including control groups $(n=6)$

\begin{tabular}{|c|c|c|c|c|c|c|c|}
\hline \multirow{3}{*}{ Treatment groups } & \multicolumn{6}{|c|}{ Bacterial colony count $(\log 10 \mathrm{CFU} / \mathrm{ml})$} & \multirow{3}{*}{ Mean $\pm \mathbf{S E}$} \\
\hline & \multicolumn{6}{|c|}{ Rat number } & \\
\hline & $\mathbf{R} 1$ & $\mathbf{R 2}$ & $\mathbf{R 3}$ & R4 & R5 & R6 & \\
\hline Growth control* & 5.40 & 5.28 & 5.44 & 5.20 & 5.32 & 5.42 & $5.35 \pm 0.03^{\mathrm{a}}$ \\
\hline Vehicle control* & 5.44 & 5.23 & 5.39 & 5.28 & 5.36 & 5.33 & $5.34 \pm 0.03^{\mathrm{a}}$ \\
\hline Chloramphenicol* & 4.08 & 3.90 & 4.18 & 3.95 & 4.15 & 4.00 & $4.05 \pm 0.04^{b}$ \\
\hline Catechin & 4.18 & 4.26 & 4.15 & 4.20 & 4.23 & 4.08 & $4.19 \pm 0.02^{\mathrm{c}}$ \\
\hline
\end{tabular}

Means bearing different superscripts between treatment groups differ significantly $(p<0.01)$.*Data of control groups were taken from our own published research (Varia et al., 2020).

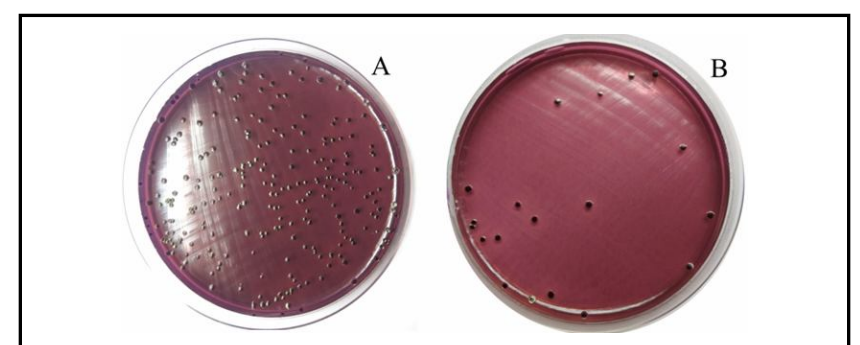

Figure 1: EMB agar plates after in vivo antibacterial assay: (A) Growth control; (B) Catechin.

\subsection{In vitro anti-inflammatory effect}

In vitro anti-inflammatory activity of catechin was measured through inhibition of NO production and COX-2 enzyme by measuring $\mathrm{PGE}_{2}$ level in LPS $(1 \mu \mathrm{g} / \mathrm{ml})$ treated RAW 264.7 macrophage cells. Per cent inhibitions of $\mathrm{NO}$ production and $\mathrm{PGE}_{2}$ compared with LPS control are depicted in Table 2. Statistically significant NO production and $\mathrm{PGE}_{2}$ inhibition were observed in catechin treated cells compared with LPS control group. Moreover, within the concentrations of catechin studied $(10 \mu \mathrm{M}, 50 \mu \mathrm{M}$ and $100 \mu \mathrm{M})$, none of the cytotoxic effect was observed and viability of the cells was more than $96 \%$ in MTT assay. 


\subsection{In vivo anti-inflammatory effect of catechin}

In present in vivo experiment, per cent oedema formation was calculated in relation to initial paw volume (supplementary data) and then percent inhibition of oedema formation was expressed in comparison to carrageenan control (Table 3). Catechin showed significant inhibition of paw edema volume in comparison to carrageenan control up to studied duration.

Table 2: Percentage inhibition of NO and PGE2 production in LPS induced RAW 264.7 cells treated with different concentrations of catechin

\begin{tabular}{|l|c|c|}
\hline Treatment group & Percent inhibition $(\%) \pm$ SE of NO production & Percent inhibition (\%) \pm SE of PGE2 production \\
\hline Positive Control* & $75.72 \pm 2.52^{\mathrm{a}}$ & $99.72 \pm 0.04^{\mathrm{a}}$ \\
Vehicle Control & $06.87 \pm 3.15^{\mathrm{b}}$ & $05.60 \pm 0.68^{\mathrm{b}}$ \\
Catechin $(10 \mu \mathrm{M})$ & $38.01 \pm 2.19^{\mathrm{c}}$ & $88.83 \pm 0.93^{\mathrm{c}}$ \\
Catechin $(50 \mu \mathrm{M})$ & $51.20 \pm 0.69^{\mathrm{d}}$ & $90.57 \pm 2.46^{\mathrm{cd}}$ \\
Catechin $(100 \mu \mathrm{M})$ & $56.25 \pm 0.99^{\mathrm{d}}$ & $94.63 \pm 1.52^{\mathrm{d}}$ \\
\hline
\end{tabular}

Means bearing different superscripts between treatment groups differ significantly $(p<0.01)$; Data of control groups were taken from our own published research (Varia et al., 2020).

Table 3: Percent inhibition (\%) of paw volumes (Mean \pm S.E.) of carrageenan induced inflammation in rats treated with drugs compared with carrageenan control $(\mathrm{n}=6)$

\begin{tabular}{|l|c|c|c|c|c|c|}
\hline Group & \multicolumn{1}{|c|}{ Hour } & 2 Hours & 3 Hours & 4 Hours & 5 Hours & 6 Hours \\
\hline Vehicle* $^{*}$ & $27.65 \pm 8.83^{\mathrm{a}}$ & $19.83 \pm 5.90$ & $14.34 \pm 3.73^{\mathrm{a}}$ & $12.63 \pm 5.24^{\mathrm{a}}$ & $14.31 \pm 4.55^{\mathrm{a}}$ & $12.37 \pm 2.80^{\mathrm{a}}$ \\
Indomethacin* & $31.32 \pm 15.35^{\mathrm{aA}}$ & $48.46 \pm 1.73^{\mathrm{A}}$ & $86.18 \pm 6.33^{\mathrm{bB}}$ & $54.80 \pm 11.57^{\mathrm{b} A \mathrm{~B}}$ & $48.90 \pm 9.88^{\mathrm{b}_{\mathrm{A}}}$ & $54.54 \pm 8.03^{\mathrm{b}_{\mathrm{AB}}}$ \\
Catechin & $73.70 \pm 11.88^{\mathrm{b}}$ & $46.49 \pm 13.80$ & $47.71 \pm 10.04^{\mathrm{c}}$ & $65.15 \pm 8.93^{\mathrm{b}}$ & $67.88 \pm 7.31^{\mathrm{b}}$ & $72.78 \pm 5.64^{\mathrm{c}}$ \\
\hline
\end{tabular}

Means bearing different superscripts in small letters between treatment groups and in capital letters within groups differ significantly $(p<0.05)$. *Data of control groups were taken from our own published research (Varia et al., 2020).

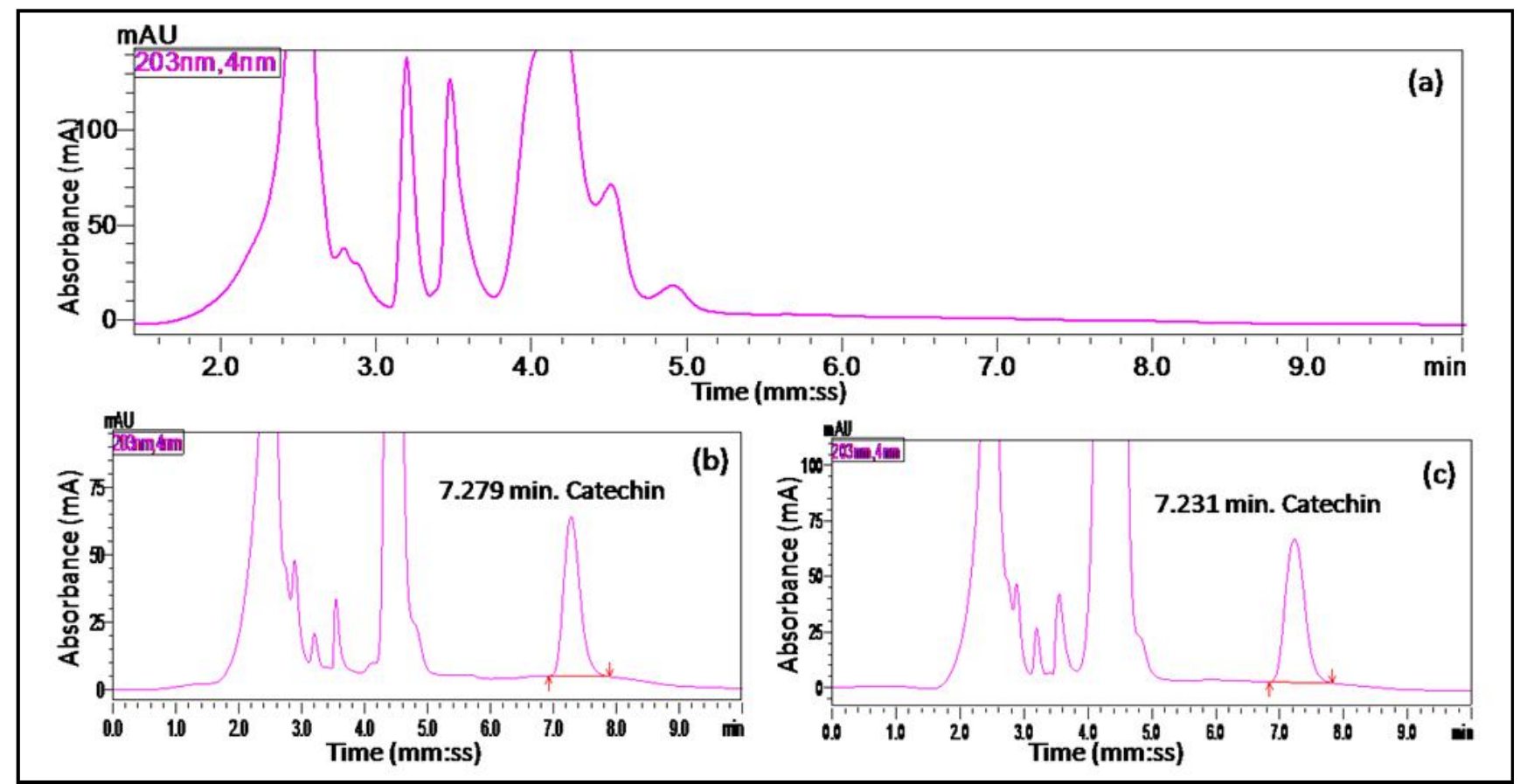

Figure 2: Representative chromatograms of (a) blank plasma of rat; (b) catechin standard in plasma (12.5 $\mu$ g/mL); (c) 45 minutes post intramuscular administration of drug in rat.

3.5 Plasma concentrations and pharmacokinetics of catechin in rat

Following single intramuscular injection of catechin $(200 \mathrm{mg} / \mathrm{kg})$, the drug concentration of $4.28 \pm 0.27 \mu \mathrm{g} / \mathrm{ml}$ was observed at $0.03 \mathrm{~h}$. The mean peak plasma drug concentration $\left(\mathrm{C}_{\mathrm{ma}}\right)$ was observed as 16.36 $\pm 0.69 \mu \mathrm{g} / \mathrm{ml}$ at $0.75 \mathrm{~h}$ which declined gradually and $0.20 \pm 0.00 \mu \mathrm{g} /$ $\mathrm{ml}$ concentration was detected at $8 \mathrm{~h}$. After that, there was no detection of catechin in plasma. Representative chromatograms and 
semi logarithmic plot of catechin concentrations in plasma versus time are given as Figures 2 and 3, respectively. Various pharmacokinetic parameters were calculated from plasma concentrations time profile after single dose intramuscular administration of catechin in rats and are summarized in Table 4.

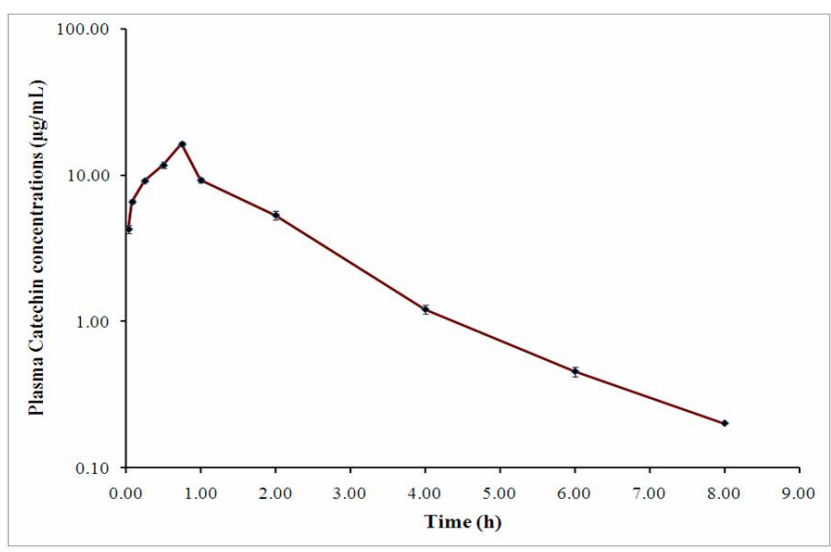

Figure 3: Semi logarithmic plot of catechin concentrations in plasma versus time following single dose $(200$ $\mathrm{mg} / \mathrm{kg}$ ) intramuscular administration in rats. Each points represents mean $\pm S E(n=6)$.

Table 4: Pharmacokinetic parameters of catechin $(200 \mathrm{mg} / \mathrm{kg})$ following intramuscular administration in rats $(n=6)$

\begin{tabular}{|c|c|c|}
\hline Pharmacokinetic parameters & Unit & Mean \pm SE \\
\hline$\alpha$ & $\mathrm{h}^{-1}$ & $1.09 \pm 0.27$ \\
\hline$\beta$ & $\mathrm{h}^{-1}$ & $0.40 \pm 0.04$ \\
\hline $\mathrm{t}_{1 / 2 \alpha}$ & $\mathrm{h}$ & $0.89 \pm 0.25$ \\
\hline$t_{1 / 2 \beta}$ & $\mathrm{h}$ & $1.79 \pm 0.17$ \\
\hline $\mathrm{C}_{\max }$ & $\mu \mathrm{g} / \mathrm{ml}$ & $16.36 \pm 0.69$ \\
\hline $\mathrm{T}_{\max }$ & $\mathrm{h}$ & $0.75 \pm 0.00$ \\
\hline $\mathrm{AUC}_{(0-\alpha)}$ & $\mu \mathrm{g} . \mathrm{h} / \mathrm{ml}$ & $27.72 \pm 0.56$ \\
\hline AUMC & $\mu \mathrm{g} \cdot \mathrm{h}^{2} / \mathrm{ml}$ & $49.26 \pm 1.68$ \\
\hline $\mathrm{Vd}_{\text {area }}$ & $\mathrm{L} / \mathrm{kg}$ & $18.62 \pm 1.54$ \\
\hline $\mathrm{Cl}_{\mathrm{B}}$ & $\mathrm{L} / \mathrm{h} / \mathrm{kg}$ & $7.23 \pm 0.15$ \\
\hline MRT & $\mathrm{h}$ & $1.78 \pm 0.03$ \\
\hline
\end{tabular}

$\alpha$-distribution rate constant; $\beta$-elimination rate constant; $t_{1 / 2 \alpha}$ distribution half life; $\mathrm{t}_{1 / 2 \beta}$ - elimination half life; $\mathrm{C}_{\max }$ - maximum plasma concentration; $\mathrm{T}_{\max }$ - time at maximum plasma concentration achieved; AUC $_{(0-\alpha)}$ - area under concentration; AUMC- area under the moment curve; $\mathrm{Vd}_{\text {area }}$ - volume of distribution; $\mathrm{Cl}_{\mathrm{B}}$ - total body clearnace; MRT mean residence time.

\section{Discussion}

\subsection{Antibacterial activity of catechin}

In the present study MICs were observed for catechin from 1.25 to $10.0 \mathrm{mg} / \mathrm{ml}$ against various bacteria. In contrast to present study, higher MIC values of catechin were observed as $>25 \mathrm{mg} / \mathrm{ml}, 8 \mathrm{mg} / \mathrm{ml}$ and $>25 \mathrm{mg} / \mathrm{ml}$ against Staphylococcus aureus, Streptococcus spp. and Bacillus subtilis, respectively (Musdja et al., 2017), whereas, lower MIC values of catechin were observed as $600 \mu \mathrm{g} / \mathrm{ml}$ against Escherichia coli, Pseudomonas aeruginosa and Staphyloccus aureus
(Ajiboye et al., 2016), $7.24 \mu \mathrm{g} / \mathrm{ml}$ against Pseudomonas aeruginosa ATCC 27853 (Saadat et al., 2013), >1024 $\mu \mathrm{g} / \mathrm{ml}$ against Staphylococcus aureus ATCC 25923, Escherichia coli ATCC 25922, Pseudomonas aeruginosa ATCC 9027 (Silva Gomes et al., 2018). Moreover, in vivo experiment did not observed significantly decreased colony forming unit (CFU) in prostate and urine culture compared with the control rats in chronic bacterial prostitis model (Lee et al., 2005), which is in contrast to significant in vivo result of present study. In vitro and in vivo results may differ due to different vehicles used to dissolve catechin and its solubility.

\subsection{Anti-inflammatory activity of catechin}

In the present in vitro anti-inflammatory study, catechin (10,50 and $100 \mu \mathrm{M}$ ) was observed to have significant inhibition on nitric oxide (NO) and $\mathrm{PGE}_{2}$ production in LPS induced macrophage cells. In accordance to present study, dose dependent in vitro inhibition of NO production on LPS induced murine macrophage was observed as $62.22 \%, 71.23 \%$ and $74.31 \%$ at dose of catechin, i.e., $17.23 \mu \mathrm{M}$, $34.45 \mu \mathrm{M}$ and $86.13 \mu \mathrm{M}$, respectively (Guruvayoorappan and Kuttan, 2008). In addition to this, dose dependent inhibitory activity of catechin on the production of NO in LPS-stimulated RAW 264.7 cells was revealed (Choi et al., 2018; Taira et al., 2012). Moreover, percent inhibition of NO production was observed as $52.58 \pm 0.76 \%$ and significant percent inhibition of $\mathrm{PGE}_{2}$ production was observed as $43.45 \pm 0.76 \%$ in LPS induced RAW 264.7 macrophage cells following treatment of Psidium guajava (guava) leaf extract $(30 \mu \mathrm{g} /$ $\mathrm{mL}$ ) containing catechin (Jang et al., 2013). Similarly, significant dose dependent reduction of $\mathrm{PGE}_{2}$ level was observed from the supernatant of cultured synoviocytes stimulated by LPS (Tang et al., 2007). Present in vivo study also showed significant antiinflammatory effect of catechin following intramuscular administration. In agreement to this result, percent inhibition of $59.19 \%$ was observed following oral administration of catechin $(100 \mathrm{mg} / \mathrm{kg})$ in rats (Musdja et al., 2019). Results from present study and previous observed data indicate that catechin have significant in vivo anti-inflammatory efficacy that may reflected as significant in vitro inhibition of inflammatory mediators.

\subsection{Plasma levels and pharmacokinetics of catechin}

Catechin concentrations in plasma were detected following single intramuscular administration at dose of $200 \mathrm{mg} / \mathrm{kg}$, wherein, $\mathrm{C}_{\max }$ was observed as $16.36 \pm 0.69 \mu \mathrm{g} / \mathrm{ml}$ which is higher than detected in rat plasma after oral administration viz. $3.39 \pm 0.63 \mu \mathrm{g} / \mathrm{mL}$ (Xie $e t$ al., 2011); $0.09 \pm 0.04 \mu \mathrm{g} / \mathrm{ml}$ (Zhang et al., 2012); $0.20 \pm 0.03 \mu \mathrm{g} / \mathrm{ml}$, $0.33 \pm 0.05 \mu \mathrm{g} / \mathrm{ml}$ and $0.40 \pm 0.07 \mu \mathrm{g} / \mathrm{ml}$ at different dose rate in rats (Huo et al., 2016) and $3.35 \pm 0.16 \mu \mathrm{g} / \mathrm{ml}$ in rabbit (Liu et al., 2003). Similar $\mathrm{T}_{\max }$ to the present study was observed after oral administration in rat $0.75 \mathrm{~h}$ (Xie et al., 2011) and $0.78 \pm 0.11 \mathrm{~h}$ in rabbit (Liu et al., 2003) whereas, lower $\mathrm{T}_{\max }$ reported as $0.15 \pm 0.09$ $\mathrm{h}$ (Zhang et al., 2012) and higher $\mathrm{T}_{\max }$ reported as $1.4 \pm 0.5 \mathrm{~h}, 1.4 \pm$ $0.6 \mathrm{~h}$ and $1.4 \pm 0.3 \mathrm{~h}$ at different dose rate in rat (Huo et al., 2016). Higher maximum plasma drug concentration in present study may be due to compatibility of drug in used vehicle and more plasma protein free drug in circulation. In present study, AUC was detected as $27.72 \pm 0.56 \mu \mathrm{gh} / \mathrm{ml}$, which is higher than reported in rats after oral administration as $16.70 \pm 2.36 \mu \mathrm{gh} / \mathrm{ml}$ (Xie et al., 2011), $0.15 \pm$ $0.10 \mu \mathrm{gh} / \mathrm{ml}$ (Zhang et al., 2012); $1.23 \pm 0.32 \mu \mathrm{gh} / \mathrm{ml}, 2.91 \pm 0.62$ $\mu \mathrm{gh} / \mathrm{ml}$ and $3.33 \pm 0.70 \mu \mathrm{gh} / \mathrm{ml}$ at different dose rate (Huo et al., 2016); in rabbits following oral and intravenous administration as 
$7.45 \pm 0.94 \mu \mathrm{gh} / \mathrm{ml}$ and $16.95 \pm 1.52 \mu \mathrm{gh} / \mathrm{ml}$, respectively (Liu et al., 2003 ) and following intravenous administration as $2.65 \pm 0.32 \mu \mathrm{gh} /$ $\mathrm{ml}$ (Ho et al., 1995). High $\mathrm{C}_{\max }$ and AUC values observed in present study showed good exposure of catechin in body may be due to intramuscular route of administration bypasses the first pass metabolism as observed in oral route.

Another important pharmacokinetic parameter observed in present study was elimination half-life $t_{1 / 2 \beta}(1.79 \pm 0.17 \mathrm{~h})$ which is in agreement with half-life reported as $2.9 \pm 1.1 \mathrm{~h}$ in rat (Huo et al., 2016). In contrast, higher half-life reported in rats as $12.43 \pm 4.04 \mathrm{~h}$ (Xie et al., 2011) and $6.38 \pm 4.20$ (Zhang et al., 2012) after oral administration and lower half-life reported in rabbits following intravenous administration as $0.73 \pm 0.1 \mathrm{~h}$ (Ho et al., 1995), $0.58 \pm$ $0.02 \mathrm{~h}$ (Liu et al., 2003) and oral administration in rabbit as $0.79 \pm$ $0.11 \mathrm{~h}$ (Liu et al., 2003). Half life greatly depends on route of administration of drug and subject to species variation. In general, oral route may have higher half life than injectable routes may be due to slow absorption and enterohepatic circulation of drug. Volume of distribution and total body clearance measured in present study were $18.62 \pm 1.54 \mathrm{l} / \mathrm{kg}$ and $7.23 \pm 0.15 \mathrm{l} / \mathrm{h} / \mathrm{kg}$, respectively. In contrast, lower volume of distribution reported as $1.12 \pm 0.14 \mathrm{l} / \mathrm{kg}$ (Ho et al., 1995 ) and $2.97 \pm 0.11 \mathrm{l} / \mathrm{kg}$ (Liu et al., 2003) in rabbits after intravenous administration. Similarly, body clearance was also found lower as $4.8 \pm 0.66 \mathrm{l} / \mathrm{h} / \mathrm{kg}[30]$ and $3.53 \pm 0.10 \mathrm{l} / \mathrm{h} / \mathrm{kg}$ (Liu et al., 2003) in rabbits. In present study MRT value was observed as $1.78 \pm 0.03 \mathrm{~h}$ following intramuscular administration of catechin and it was found lower than reported $3.98 \pm 0.33 \mathrm{~h}$ in rat after oral administration (Zhang et al., 2012).

Catechin showed good pharmacokinetic properties with wide distribution of free drug in the body with good residence time, which proposed catechin as a good herbal molecule for antibacterial and anti-inflammatory formulation. Moreover, injectable catechin can be prepared using various compatible methods like nanostructurebased drug delivery systems, molecular modification and coadministration with some other bioactive ingredients to increase duration of action which can be helpful to use drug in practice with minimum side effects (Cai et al., 2018).

\section{Conclusion}

Catechin exhibited significant in vitro activity against studied gram positive and gram negative organisms and also found effective in neutropenic thigh infection model in rats. Further, catechin showed significant in vitro and in vivo anti-inflammatory activity. Moreover, following single intramuscular administration of catechin $(200 \mathrm{mg} /$ $\mathrm{kg}$ ), good mean residence time in rat and it may be good candidate for injectable herbal formulation. Research till date indicates that, catechin has proven antibacterial and anti-inflammatory activity make it suitable candidate to use concurrent with conventional synthetic antibacterial and anti-inflammatory drugs to reduce their dose and thereby reducing side effects as well as to combat antibacterial drug resistance.

\section{Acknowledgements}

The authors are grateful to authorities of the Veterinary College, Navsari, Gujarat, India for providing the funding and facilities to conduct the study. Authors are also thankful to Dr. Pushpa Rathod who helped to maintain cell line.

\section{Conflict of interest}

The authors declare no conflicts of interest relevant to this article.

\section{References}

Ajiboye, T.O.; Aliyu, M.; Isiaka, I.; Haliru, F.Z.; Ibitoye, O.B.; Uwazie, J.N.; Muritala, H.F.; Bello, S.A.; Yusuf, I.I. and Mohammed. A.O. (2016). Contribution of reactive oxygen species to $(+)$-catechin mediated bacterial lethality. Chem. Biol. Interact. 258:276-287. https://doi.org/10.1016/ j.cbi.2016.09.010

Akinmoladun, A.C.; Oladejo, C.O.; Josiah, S.S.; Famusiwa, C.D.; Ojo, O.B. and Olaleye, M.T. (2018). Catechin, quercetin and taxifolin improve redox and biochemical imbalances in rotenone-induced hepatocellular dysfunction: Relevance for therapy in pesticide-induced liver toxicity, Pathophysiology, 25(4):365-371. https://doi.org/10.1016/ j.pathophys.2018.07.002

Balakrishnan, N.M.N.; Punniamurthy, N.; Mekala,P.; Ramakrishnan, N. and Kumar, S.K.(2017). Ethnoveterinary formulation for treatment of bovine mastitis. J. Vet. Sci. S1., pp:25-29.

Bansal, S.; Vyas, S.; Bhattacharya, S. and Sharma, M. (2013). Catechin prodrugs and analogues: A new array of chemical entities with improved pharmacological and pharmacokinetic properties. Nat. Prod. Rep., 30(11):1438-1454. https://doi.org/10.1039/c3np70038k

Barton, M.H.; Paske, E.; Norton, N.; King, D.; Giguere, S. and Budsberg, S. (2014) Efficacy of cyclooxygenase inhibition by two commercially available firocoxib products in horses. Equine Vet. J., 46(1):72-75. doi:10. $1111 /$ evj.12095

Cai, Z.Y.; Li, X.M.; Liang, J.P.; Xiang, L.P.; Wang, K.R.; Shi, Y.L.; Yang, R.; Shi, M.; Ye, J.H.; Lu, J.L.; Zheng, X.Q. and Liang, Y.R. (2018). Bioavailability of tea catechins and its improvement. Molecules. 23(9):2346. https:// doi: 10.3390/molecules, 23092346

Choi, C.W.; Shin, J.Y.; Seo, C.; Hong, S.S.; Ahn, E.K.; Jung, Y.H. and Oh, J.S. (2018). In vitro anti-inflammatory activity of the components of Amomumtsao-ko in murine macrophage RAW 264.7 cells. Afr. J. Tradit. Complement. Altern. Med., 15(2):26-34. https://doi.org/ 10.21010/ajtcam.v15i2.4

Ferreyra, F.; Rius, S.P. and Casati, P. (2012). Flavonoids: Biosynthesis, biological functions, and biotechnological applications. Front Plant Sci., 28(3): 1-15. https://doi.org/10.3389/fpls.2012.00222

Grzesik, M.; Naparlo, K.; Bartosz, G. and Sadowska-Bartosz, I. (2018). Antioxidant properties of catechins: Comparison with other antioxidants. Food Chem. 241: 480-492. https://doi.org/10.1016/j. Food Chem. pp:8:117.

Guruvayoorappan, C. and Kuttan, G. (2008). (+)-Catechin inhibits tumour angiogenesis and regulates the production of nitric oxide and TNF$\alpha$ in LPS-stimulated macrophages. Innate Immunity, 14(3):160174. https://doi.org/10.1177/1753425908093295

Ho, Y.; Lee, Y. and Hsu, K. (1995). Determination of (+)-catechin in plasma by high-performance liquid chromatography using fluorescence detection. J. Chromatogr. B. Biomed. Appl., 665(2):383-389. https:/ /doi.org/10.1016/0378-4347(94)00535-d

Huo, Y.; Zhang, Q.; Li, Q.; Geng, B. and Bi, K. (2016). Development of a UFLCMS/MS method for the simultaneous determination of seven tea catechins in rat plasma and its application to a pharmacokinetic study after administration of green tea extract. J. Pharm. Biomed. Anal., 125:229-235. https://doi.org/10.1016/j.jpba.2016.03.048

Jang, M.; Jeong, S.W.; Cho, S.K.; Ahn, K.S.; Kim, B.K. and Kim, J.C. (2013). Antiinflammatory effects of 4 medicinal plant extracts in 
lipopolysaccharide-induced RAW 264.7 Cells. Food Sci. Biotechnol., 22(1):213-220. https://doi.org/10.1007/s10068-013-0069-x

Lee, Y.S.; Han, C.H.; Kang, S.H.; Lee, S.J.; Kim, S.W.; Shin, O.R.; Sim, Y.C.; Lee, S.J. and Cho, Y.H. (2005). Synergistic effect between catechin and ciproûoxacin on chronic bacterial prostatitis rat model. Int. J. Urol, 12(4):383-389. https://doi.org/10.1111/j.1442-2042.2005. 01052.x

Liu, X.X.; Cheng, T.; Sun, Z.; Xu, J.P. and He, X.R. (2003). Study on pharmacokinetics and bioavailability of catechin in rabbits. Journal of Traditional Chinese Veterinary Medicine., 2. https://en.cnki. com.cn/Article_en/CJFDTotal-SPKX200305035.htm

Malik, T.; Madan, V.K and Prakash, R. (2020). Herbs that heal: Floristic boon to the natural healthcare system. Ann. Phytomed., 9(2):6-14. DOI: http://dx.doi.org/10.21276/ap.2020.9.2.2

Mereles, D. and Hunstein, W. (2011). Epigallocatechin-3-gallate (EGCG) for clinical trials: more pitfalls than promises? Int. J. Mol. Sci., 12(9): 5592-5603. https://doi.org/10.3390/ijms 12095592

Musdja, M.Y.; Hapsari, M.A. and Agusta, A. (2017). Comparison of activity and inhibitory mechanism between (+)-catechin and water extract of Gambier (Uncaria gambir roxb.) against some bacteria. Scientific journal of PPI-UKM., 4(2):55-60. https://doi.org/10.27512/sjppiukm/se/a29012018

Musdja, M.Y.; Suryani, N. and Pitriyah, P. (2019). Anti-inflammatory activity of Catechins isolate of Uncaria gambir Roxb. on carrageenan induced paw edema in wistar male rats. Int. J. Rec. Adv. Multidisc. Res., 6(1):4518-4521.

Nayanabhirama, U. (2016). Status on herbal drugs and their future properties. Ann. Phytomed., 5(1):1-3.

Parveen, B.; Parveen, A.; Parveen, R.; Ahmed, S.; Ahmed, M. and Iqbal, M. (2020) Challenges and opportunities for traditional herbal medicine today with special reference to its status in India. Ann. Phytomed., 9(2): 97-112. DOI: http://dx.doi.org/10.21276/ap.2020.9.2.8

Saadat, M.; Roudbarmohammadi, S.; Yadegari, M. and Khavarinejad, R. (2013). Evaluation of antibacterial effects of catechin and EDTA on planktonic and biofilm cells of Pseudomonas aeruginosa. Malays. J. Microbiol., 9(2):184-188. https://doi.org/10.21161/mjm.46912

Silva Gomes, F.M.; da Cunha Xavier, J.; dos Santos, J.F.S.; de Matos, Y.M.L.S.; Tintino, S.R.; de Freitas, T.S. and MeloCoutinho, H.D. (2018). Evaluation of antibacterial and modifying action of catechin antibiotics in resistant strains. Microb. Pathog., 115:175-178. https://doi.org/10.1016/ j.micpath.2017.12.058
Suebsasana, S.; Pongnaratorn, P.; Sattayasai, J.; Arkaravichien, T.; Tiamkao, S. and Aromdee, C. (2009). Analgesic, antipyretic, anti-Inflammatory and toxic effects of andrographolide derivatives in experimental animals. Arch. Pharm. Res., 32(9):1191-1200. https://doi.org/ $10.1007 / \mathrm{s} 12272-009-1902-\mathrm{x}$

Taira, J.; Ohmine, W.; Ogi, T.; Nanbu, H. and Ueda, K. (2012). Suppression of nitric oxide production on LPS/IFN $\gamma$ stimulated RAW 264.7 macrophages by a novel catechin, pilosanol N, from Agrimonia pilosa Ledeb. Bioorg. Med. Chem. Lett., 22(4):1766-1769. https:/ /doi.org/10.1016/j.bmcl.2011.12.086

Tang, L.Q.; Wei, W. and Wang, X.Y. (2007). Effects and mechanisms of catechin for adjuvant arthritis in rats. Adv. Ther., 24(3):679-690. https:// doi.org/10.1007/BF02848793

Tapas, A.R.; Sakarkar, D.M.; Kakde, R.B. and Beydemir, S. (2008). Flavonoids as nutraceuticals: A review. Trop. J. Pharm. Res., 7(3):1089-1099. https://doi.org/10.4314/tjpr.v7i3.14693

Tsuchiya H. (2001). Stereospecificity in membrane effects of catechins. Chem. Biol. Interact., 134(1):41-54. https://doi.org/10.1016/s00092797(00)00308-2

Varia, R.D.; Patel J.H.; Modi, F.D.; Vihol, P.D. and Bhavsar, S.K. (2020). In vitro and in vivo antibacterial and anti-inflammatory properties of Linalool. Int. J. Curr. Microbiol. App. Sci., 9(9):1481-1489. https://doi.org/ 10.20546/ijcmas.2020.909.187

Wiegand, I.; Hilpert, K. and Hancock, R.E.W. (2008). Agar and broth dilution methods to determine the minimal inhibitory concentration (MIC) of antimicrobial substances. Nat. Protoc., 3(2):163-175. https:// doi.org/10.1038/nprot.2007.521

Xie, L.; Li, X.; Jiang, D. and Zhang, D. (2011). Determination and pharmacokinetic study of catechin in rat plasma by HPLC. J Pharm. Anal., 1(4):297-301. https://doi.org/10.1016/j.jpha.2011.09.004

Zhang, Q.H.; Wang, W.B.; Li, J.; Chang, Y.X.; Wang, Y.F.; Zhang, J.; Zhang, B.L. and Gao, X.M. (2012). Simultaneous determination of catechin, epicatechin and epicatechingallate in rat plasma by LC-ESI-MS/MS for pharmacokinetic studies after oral administration of Cynomorium songaricum extract. J. Chromatogr. B. Analyt. Technol. Biomed. Life Sci., 880(1): 168-171. https://doi.org/10.1016/j.jchromb. 2011.11 .021

Zhao, M.; Lepak, A.J. and Andes, D.R. (2016). Animal models in the pharmacokinetic/pharmacodynamic evaluation of antimicrobial agents. Bioorg. Med. Chem., 24(24):6390-6400. https://doi.org/ 10.1016/j.bmc.2016.11.008. 